УДК 619:636.2:616.71-007.233-07

(C) 2015

Маслак Ю. В., кандидат ветеринарних наук,

Собакар А. В., асистент

Харківська державна зооветеринарна академія

\title{
ЕТІОПАТОГЕНЕЗ ОСТЕОДИСТРОФІЇ У КІЗ ЗААНЕНСЬКОЇ ПОРОДИ
}

\section{Рецензент - кандидат ветеринарних наук О. В. Маценко}

Встановлено, шо аліментарна остеодистрофія кіз молочних порід характеризується як клінічними ознаками, так і специифічною динамікою біохімічних показників, які відображують як зміни загального метаболічного статусу тварин, так $і$ стану сполучної тканини, зокрема кісткової. Це вміст глікопротеїнів, загальних хондроїтинсульфатів, окремих фракиій глікозаміногліканів, активність лужної фосфатази та ї̈ кісткового ізоферменту, кислої фосфатази, загального та іонізованого кальиію $i$ фосфору $y$ сироватиі крові тварин.

Ключові слова: кози, остеодистрофія, сироватка крові, етіопатогенез, сполучна тканина.

Постановка проблеми. В останні роки в Україні постійно зростає поголів'я кіз молочних порід, оскільки спостерігається тенденція до збільшення вживання козиного молока та продуктів його переробки $[4,8]$. Проте тварин часто утримують на раціонах з дефіцитом енергії, протеїну, макро- і мікроелементів, вітамінів, що призводить до порушення обміну речовин [3].

Основними чинниками остеодистрофії у тварин $\epsilon$ порушення годівлі та гіподинамія, а провідними ланками іiі патогенезу - дисбаланс між формуванням і резорбцією кістки. Роль аліментарного фактора полягає у незбалансованій та недостатній годівлі тварин. Особливе значення має недостатнє надходження 3 кормами кальцію i фосфору та порушення співвідношення цих елементів у раціонах.

Окрім вмісту кальцію та фосфору в раціоні, необхідно також враховувати вміст мікроелементів. С. П. Долецький встановив, що в етіології остеодистрофії певну роль відіграє нестача кобальту, цинку, купруму, мангану [4]. Відомо, що мікроелементи беруть активну участь в окиснювально-відновних процесах, тканинному диханні, а також утворенні кісткової тканини та механізмах регенерації в разі ушкодження кісток. Кобальт належить до остеогенних мікроелементів: він активує лужну фосфатазу, і тому за його нестачі порушуються процеси кісткоутворення і розвивається остеодистрофія. За дефіциту кобальту у тварин спостерігають порушен- ня функцій щитоподібної залози, бо мікроелемент необхідний для синтезу стероїдних гормонів $[9,12]$.

Купрум входить до складу багатьох ферментів, у тому числі лізилоксидази, яка каталізує утворення поперечних зв'язків у колагені та еластині для забезпечення міцності кісток і сполучної тканини. За дефіциту купруму в кістковій тканині тварин підвищується вміст розчинного колагену і затримується перетворення його у зрілий колаген $[9,20]$.

Цинк стимулює активність лужної фосфатази, бере участь у процесах кальцифікації [13].

Проте біохімічні тести, що характеризують стан мінерального гомеостазу, змінюються лише за істотних порушень системи ендокринної регуляції та метаболізму кісткової тканини, а відомості щодо стану органічної складової кісткової тканини в кіз за норми та остеодистрофії досить обмежені [19].

Аналіз останніх досліджень і публікацій, у яких започатковано розв'язання проблеми. Вивченню патології мінерального обміну, зокрема остеодистрофії у сільськогосподарських тварин, присвячено багато робіт $[1,7]$, проте відомостей щодо остеодистрофії кіз у наукових публікаціях обмаль $[17,18]$.

Мета досліджень - встановити етіопатогенетичні ланки остеодистрофії у кіз зааненської породи.

Завдання досліджень - встановити найбільш інформативні біохімічні показники в сироватці крові кіз за остеодистрофії.

Матеріал і методи дослідження. Дослід проводився на козах зааненської породи, які належать до ННЦ тваринництва і рослинництва Харківської державної зооветеринарної академії, кількістю 20 голів, віком 3-5 років, продуктивністю 700 кг за лактацію. Об'єктом досліджень у дослідних групах були хворі на остеодистрофію кози.

У сироватці крові кіз визначали: неорганічний фосфор та магній - спектрофотометричним методом; калій, натрій і кальцій (загальний та іоні- 


\section{ВЕТЕРИНАРНА МЕДИЦИНА}

зований) - за допомогою аналізатора електролітів АСК-01 (K, Na, Ca, pH); активність кислої (КФ) і лужної (ЛФ) фосфатаз та кісткового ізоферменту лужної фосфатази - за методом Боданські; глікопротеїни (ГП) - за методом О. П. Штейнберг та Я. Н. Доценко [10]; хондроїтинсульфати (ХCT) - за методом Nemeth-Csoka у модифікації Л. І. Слуцького; загальні глікозаміноглікани (ГАГ) та їх фракції - за методикою Ф. С. Леонтьєвої, В. А. Філіпенко, О. П. Тимошенко та інших $[10,11]$.

Результати дослідження. Раціон кіз включав сіно злаково-різнотравне - 2 кг та дерть ячмінну - 0,2 кг. Структура - грубі корми - 90,9 \%, концентровані - 9,1 \%. Раціон виявився незбалансованим за основними поживними речовинами. Забезпеченість кормовими одиницями становила $95,8 \%$, перетравним протеїном - 90,0 \%. В раціоні містився надлишок кальцію (189,3\% до потреби) та магнію. Кальціє-фосфорне співвідношення складало 3,39:1 (за норми - 1,78:1). Раціон виявився дефіцитним за купрумом, цинком та кобальтом на 54,2, 75,2 та 17,4 \% відповідно.

Відомо, що надлишок у раціоні солей магнію негативно впливає на процеси всмоктування кальцію. Можливо, у зв'язку з дефіцитом цинку в раціоні відбувається порушення процесу ремоделювання кісткової тканини, оскільки цинк стимулює активність лужної фосфатази; і знижується зольність кісток, оскільки цей мікроелемент бере участь у процесах кальцифікації [14].

Йони купруму в процесі росту і диференціації остеокластів здійснюють регулюючий вплив на остеогенні клітинні елементи та процеси оссифі- кації, каталізують ферментативні реакції в остеобластах, відіграють суттєву роль у функції ферментів, які беруть участь у процесі утворення колагену. Нестача купруму веде до зниження вмісту оксипроліну i кальцію в кістках, зменшення ступеня мінералізації кісток, сприяє виведенню фосфору $з$ організму. Прояв нестачі купруму формує дефектний синтез колагену, що супроводжується деформацією скелета і призводить до розвитку дифузного остеопорозу.

Кобальт регулює мінеральний обмін, підвищує активність кісткової фосфатази та ряду інших ферментів остеогенезу. Тому за його нестачі порушуються процеси синтезу органічної і мінеральної частини кістки. За даними Г. І. Назаренко дефіцит кобальту може спричинити атрофію слизової оболонки травного каналу, що викликає порушення всмоктування поживних речовин та мікроелементів [16].

На основі літературних даних і результатів наших досліджень були встановлені етіологічні чинники і провідні ланки патогенезу остеодистрофії кіз.

Нами встановлено, що в патогенезі аліментарної остеодистрофії кіз провідну роль відіграють порушення обміну біополімерів кісткової тканини - колагену та протеогліканів, які зазнають дистрофічних змін, елімінуючи 3 кісток тварин, внаслідок дефіциту в раціоні поживних речовин, мікроелементів, вітаміну D, відсутності моціону та недостатньої природної інсоляції. Це призводить до демінералізації, деполімерізації органічних компонентів та резорбції кісткової тканини.

\section{1. Показники мінерального обміну у сироватці крові клінічно здорових та хворих на остеодистрофію кіз}

\begin{tabular}{|c|c|c|c|}
\hline Показник & $\begin{array}{c}\text { Біометричний } \\
\text { показник }\end{array}$ & $\begin{array}{c}\text { Клінічно здорові кози, } \\
\mathrm{n}=10\end{array}$ & $\begin{array}{c}\text { Хворі на остеодистрофію } \\
\text { кози, } \mathrm{n}=10\end{array}$ \\
\hline \multirow{2}{*}{$\begin{array}{l}\text { Са заг., } \\
\text { ммоль/л }\end{array}$} & Lim & $2,38-2,71$ & $2,58-3,08$ \\
\hline & $\mathrm{M} \pm \mathrm{m}$ & $2,62 \pm 0,03$ & $2,80 \pm 0,05 * *$ \\
\hline \multirow{2}{*}{$\begin{array}{l}\text { Са іон., } \\
\text { ммоль/л }\end{array}$} & Lim & $1,04-1,23$ & $1,15-1,54$ \\
\hline & $\mathrm{M} \pm \mathrm{m}$ & $1,16 \pm 0,01$ & $1,33 \pm 0,03 * * *$ \\
\hline \multirow{2}{*}{ Р, ммоль/л } & Lim & $1,21-1,55$ & $1,15-1,34$ \\
\hline & $\mathrm{M} \pm \mathrm{m}$ & $1,35 \pm 0,04$ & $1,24 \pm 0,02 *$ \\
\hline \multirow{2}{*}{$\mathrm{Ca} / \mathrm{P}$} & Lim & $1,70-2,25$ & $1,98-2,49$ \\
\hline & $\mathrm{M} \pm \mathrm{m}$ & $1,92 \pm 0,10$ & $2,26 \pm 0,06 * *$ \\
\hline \multirow{2}{*}{$\begin{array}{c}\mathrm{Mg}, \\
\text { ммоль/л }\end{array}$} & Lim & $0,84-0,94$ & $0,79-0,93$ \\
\hline & $\mathrm{M} \pm \mathrm{m}$ & $0,89 \pm 0,01$ & $0,87 \pm 0,01$ \\
\hline
\end{tabular}

Примітка: $*-\mathrm{p}<0,05, * *-\mathrm{p}<0,01, * * *-\mathrm{p}<0,001$ за порівняння контрольної та дослідних груп тварин 
BETЕРИНАРНА МЕДИЦИНА

\section{2. Показники активності ферментів у сироватці крові клінічно здорових та хворих на остеодистрофію кіз}

\begin{tabular}{|c|c|c|c|}
\hline Показник & $\begin{array}{c}\text { Біометричний } \\
\text { показник }\end{array}$ & $\begin{array}{c}\text { Клінічно здорові кози, } \\
\mathrm{n}=10\end{array}$ & $\begin{array}{c}\text { Хворі на остеодистрофію } \\
\text { кози, } \mathrm{n}=10\end{array}$ \\
\hline \multirow{2}{*}{ ЛФ, од. Бод. } & $\mathrm{Lim}$ & $2,0-6,8$ & $4,4-13,0$ \\
\cline { 2 - 4 } & $\mathrm{M} \pm \mathrm{m}$ & $4,15 \pm 0,49$ & $8,31 \pm 1,09 * *$ \\
\hline $\begin{array}{c}\text { Кістковий ізофермент } \\
\text { ЛФ, у проц. }\end{array}$ & $\mathrm{Lim}$ & $50,0-68,0$ & $60,0-79,0$ \\
\cline { 2 - 4 } & $\mathrm{M} \pm \mathrm{m}$ & $60,8 \pm 1,99$ & $70,2 \pm 2,98 *$ \\
\hline \multirow{2}{*}{ КФ, од. Бод. } & $\mathrm{Lim}$ & $1,0-6,1$ & $4,2-10,9$ \\
\cline { 2 - 4 } & $\mathrm{M} \pm \mathrm{m}$ & $3,07 \pm 0,57$ & $7,94 \pm 1,34 * *$ \\
\hline
\end{tabular}

Примітка: $*-\mathrm{p}<0,05, * *-\mathrm{p}<0,01, * * *-\mathrm{p}<0,001$ за порівняння контрольної та дослідних груп тварин.

Були досліджені біохімічні показники сироватки крові тварин, хворих на остеодистрофію. Результати наведені у таблицях.

Рівень загального кальцію у сироватці крові кіз із клінічними ознаками остеодистрофії був підвищеним на $6,8 \%(\mathrm{p}<0,01)$ за рахунок зростання концентрації іонізованого кальцію на $14,7 \%$ $(\mathrm{p}<0,01)$ внаслідок його елімінації 3 кісткової тканини, водночас вміст фосфору був зменшеним на $8,1 \%(\mathrm{p}<0,05)$.

Можливо така динаміка відбувається за рахунок підвищення вмісту ПТГ, який різноспрямовано впливає на вміст кальцію і фосфору в сироватці крові, сприяючи підвищенню концентрації кальцію і зниженню концентрації фосфатів. Biдомо, що за дефіциту вітаміну $\mathrm{D}_{3}$ рівень ПТГ в організмі підвищується $[2,15]$. Активність лужної фосфатази у сироватці крові кіз дослідної групи була підвищена на 100,2 \%, скоріш за все, за рахунок збільшення активності кісткового ізоферменту на 15,4 \%. У тварин цієї ж групи 3 клінічними ознаками остеодистрофії, була збільшена й активність кислої фосфатази у сироватці крові на $158,6 \%$.

Активність кислої фосфатази є більш специфічним показником для оцінки стану кісткової тканини, оскільки цей фермент міститься в остеокластах. Підвищення його рівня свідчить про посилення інтенсивності резорбції кісткової тканини, яка зростає за остеодистрофії.

За клінічного перебігу остеодистрофії у сироватці крові кіз був збільшеним уміст наступних показників: загальних ГАГ на 19,4 \% (p<0,01), II фракції ГАГ на $27,7 \%$, III фракції на $111,5 \%$, а загальних хондроїтинсульфатів - на 200 \% відповідно.

\section{3. Показники сполучної тканини в сироватці крові клінічно здорових та хворих на остеодистрофію кіз}

\begin{tabular}{|c|c|c|c|}
\hline Показник & Біометричний показник & $\begin{array}{c}\text { Клінічно здорові кози, } \\
\text { n=10 }\end{array}$ & $\begin{array}{c}\text { Хворі на остеодистрофію } \\
\text { кози, } \mathrm{n}=10\end{array}$ \\
\hline \multirow{2}{*}{ ГП, ум.од. } & Lim & $0,45-0,63$ & $0,38-0,86$ \\
\hline & $\mathrm{M} \pm \mathrm{m}$ & $0,52 \pm 0,01$ & $0,58 \pm 0,04$ \\
\hline \multirow{2}{*}{ ХСТ, г/л } & Lim & $0,050-0,099$ & $0,109-0,460$ \\
\hline & $\mathrm{M} \pm \mathrm{m}$ & $0,080 \pm 0,01$ & $0,240 \pm 0,04 * *$ \\
\hline \multirow{2}{*}{$\begin{array}{c}\text { Загальні ГАГ, } \\
\text { ум. од. }\end{array}$} & Lim & $9,8-14,2$ & $9,5-19,9$ \\
\hline & $\mathrm{M} \pm \mathrm{m}$ & $11,89 \pm 0,38$ & $14,18 \pm 0,84 *$ \\
\hline \multirow{2}{*}{$\begin{array}{l}\text { I фракція, } \\
\text { ум. од. }\end{array}$} & Lim & $6,2-10,1$ & $6,5-12,3$ \\
\hline & $\mathrm{M} \pm \mathrm{m}$ & $7,99 \pm 0,53$ & $8,11 \pm 0,54$ \\
\hline \multirow{2}{*}{$\begin{array}{l}\text { II фракція, } \\
\text { ум. од. }\end{array}$} & Lim & $1,9-3,4$ & $2,4-4,3$ \\
\hline & $\mathrm{M} \pm \mathrm{m}$ & $2,60 \pm 0,16$ & $3,32 \pm 0,20 *$ \\
\hline \multirow{2}{*}{$\begin{array}{l}\text { III фракція, } \\
\text { ум. од. }\end{array}$} & Lim & $1,1-1,6$ & $1,5-4,8$ \\
\hline & $\mathrm{M} \pm \mathrm{m}$ & $1,30 \pm 0,05$ & $2,75 \pm 0,31 * * *$ \\
\hline
\end{tabular}

Примітка: $*-\mathrm{p}<0,05, * *-\mathrm{p}<0,01, * * *-\mathrm{p}<0,001$ за порівняння контрольної та дослідних груп тварин 
Це означає, що за клінічно вираженої остеодистрофії у сироватці крові зростає вміст хондроїтин-4-сульфату, який в основному переважає у складі міжклітинного матриксу саме кісткової тканини, що підтверджує посилення в ній катаболічних процесів. Те, що саме на цій стадії остеодистрофії підвищується концентрація III фракції ГАГ, в якій містяться кератан- та гепарансульфати, може бути пояснено тим, що в патологічний процес залучається сполучна тканина не тільки кісток, але й печінки, міжхребцевих дисків, судин та ін. Тобто на цій стадії остеодистрофія може ставати ланкою поліорганної патології (табл. 3).

Серед біохімічних компонентів найбільш інформативними для діагностики остеодистрофії 3 вираженими клінічними ознаками $є$ визначення

\section{БІБЛІОГРАФІЯ}

1. Борисевич Б. В. Етіологія, патогенез і патоморфологія остеодистрофії великої рогатої худоби : автореф. дис. на здобуття наук. ступеня д.вет.н. : спец. 16.00.02 «Патологія, онкологія і морфологія тварин» / Б. В. Борисевич. - К., 1999. $35 \mathrm{c}$.

2. Витамин D и костная система / [Г. В. Гайко, A. В. Калашников, А. Т. Бруско и др.] - К. : Книга плюс, 2008. - $176 \mathrm{c}$.

3. Влізло В. В. До етіології та діагностики хвороб печінки у кіз / В. В. Влізло, І. А. Максимович // Вісник аграрної науки. - 2006. - №9. C. $43-46$.

4. Давиденко М. Д. Чому занепадає козівництво? / М. Д. Давиденко // Тваринництво України. 2009. - №7. - С. 9-10.

5. Долецкий С.П. Экспресс-диагностика и профилактика энзоотической остеодистрофии у молочных коров : автореф. дис. на соиск. уч. степени к.вет.н. : спец. 16.00.01 «Диагностика и терапия животных» / С. П. Долецкий. - К., 1989. $-18 \mathrm{c}$.

6. Назаренко Г. И., Кишкун А. А. Клиническая оценка результатов лабораторних исследований / Г. И. Назаренко, А. А. Кишкун. - М. : ОАО изд-во «Медицина», 2006. - 543 с.

7. Кондрахин И. П. Вторичная остеодистрофия коров / И. П. Кондрахин // Ветеринария. - 1980. №9. - С. 52-55.

8. Марзанов Н. И. Разведение коз полезно для здоровья / Н. И. Марзанов, Г. В. Дерюгин // Главный зоотехник. - 2006. - №4. - С. 68.

9. Мікроелементози сільськогосподарських тварин / [М. О. Судаков, М. І. Оніпенко, В. С. Ко- вмісту в сироватці крові: хондроїтинсульфатів, II та III фракцій ГАГ, активності лужної фосфатази та іiі кісткового ізоферменту, активності кислої фосфатази.

Висновок. Отже, аліментарна остеодистрофія кіз молочних порід характеризується як клінічними ознаками, так і специфічною динамікою біохімічних показників, які відображують як зміни загального метаболічного статусу тварин, так і стану сполучної тканини, зокрема кісткової.

У сироватці крові - це вміст глікопротеїнів, загальних хондроїтинсульфатів, окремих фракцій глікозаміногліканів, активність лужної фосфатази та ії кісткового ізоферменту, кислої фосфатази, загального та іонізованого кальцію і фосфору у сироватці крові тварин.

зачок та ін.] ; за ред. професора М. О. Судакова. К. : Урожай, 1974. - 152 с.

10. Пат. 28147 Україна, МПК G 01N 33/53. Спосіб визначення гексозаміногліканів / Ф. С. Леонтьєва, О. П. Тимошенко, М. І. Карташов та ін. ; заявник та власник державна установа «Інститут патології хребта та суглобів ім. проф. М. І. Ситенка АМНУ» та Харківська державна зооветеринарна академія. - № 200708506 ; заявл. 24.07.07 ; опубл. 26.11.07.

11. Пат. 29198 Україна, МПК G01N 33/48. Спосіб визначення фракцій сульфітованих глікозаміногліканів / Ф. С. Леонтьєва, В. А. Філіпенко, О. П. Тимошенко та ін. ; заявник та власник державна установа «Інститут патології хребта та суглобів ім. проф. М. І. Ситенка АМНУ» та Харківська державна зооветеринарна академія. № 200708505 ; заявл. 24.07.07 ; опубл. 10.01.08.

12. Стадник A. М. Остеодистрофія корів та бичків: патогенетична роль глюкокон'югатів, рання діагностика та спрямована профілактика / А. М. Стадник // Вісник Білоцерків. держ. аграр. ун-ту. - Біла Церква, 1998. - Вип. 5, Ч. 1. C. 223-225.

13. Стадник А. М. Мікроелементи в остеогенезі та їхній обмін за остеопатології / А. М. Стадник, В. Л. Федорович, О. А. Стадник // Наук. вісник Львів. нац. ун-ту вет. медицини ім. Гжицького. - Львів, 2007. - Т. 9, №1 (32). - С. 373-383.

14. Стадник А. М. Мікроелементози худоби: альтернативні методи діагностики, профілактики / А. М. Стадник, Р. Й. Кравців, М. Г. Личук // Вісник Білоцерків. держ. аграр. ун-ту. - Біла Церква, 2005. - Вип. 33. - С. 239-240. 


\section{ВЕТЕРИНАРНА МЕДИЦИНА}

15. Тишківська Н. В. D-гіповітаміноз молодняку великої рогатої худоби на відгодівлі (діагностика, лікування і профілактика) : автореф. дис. на здобуття наук. ступеня к.вет.н. : спец. 16.00.01 «Діагностика і терапія тварин» / Н. В. Тишківська. Біла Церква, 2002. - 20 с.

16. Штейнберг О. П. Определение гликопротеидов в сыворотке крови / О. П. Штейнберг, Я. Н. Доценко // Врачебное дело. - 1962. - №12. C. 43-45.

17. Braun U. Osteoporosis in goats associated with phosphorus and calcium deficiency / U. Braun, S. Ohlerth, A. Liesegang et al. // Vet. Rec. - 2009. №164 (7). - P. 211-213.

18. Cruz L. A. Osteodystrophya fibrosa in milking goats: report of a clinical case / L. A. Cruz, M. J. Lima, M. C. Peleteiro // Revista portuguesa de ciencias veterinarias. - 2002. - №97 (543). P. $147-150$.

19. Liesegang A. The effects of first gestation and lactation on bone metabolism in dairy goats and milk sheep / A. Liesegang, J. Risteli, M. Wanner // Bone. - 2006.- №38. - P. 792-802.

20. Sharma M. C. Copper status and enzyme, hormone, vitamin and immune function in heifers / M. C. Sharma, C. Joshi, N. N. Pathak et al. // Res. Vet. Sci. - 2005. - Vol. 79, №2. - P. 113-123. 